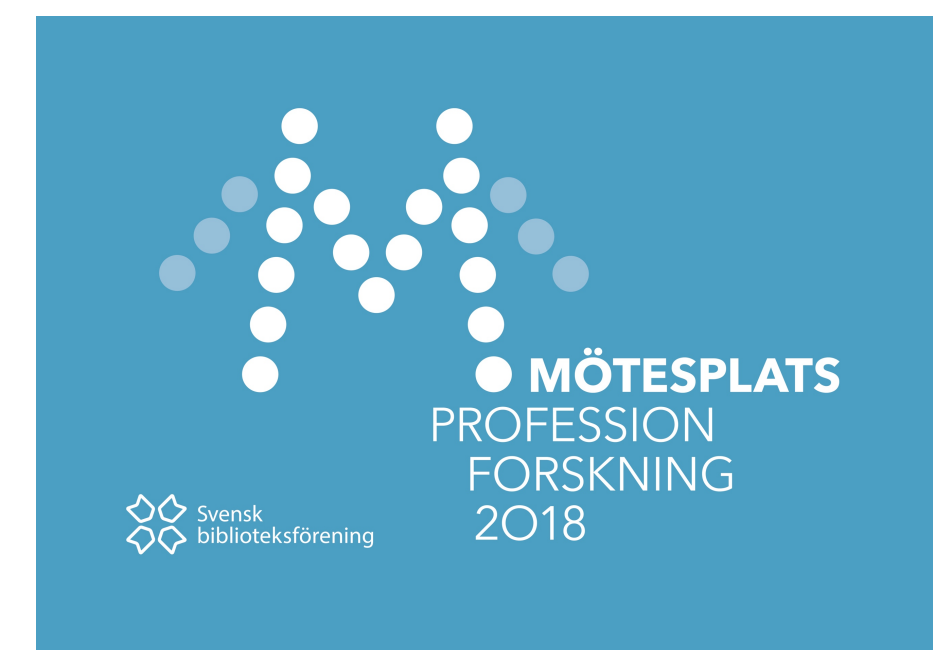

Kjellberg, S, Dorthé, L, Olsson, A, Wogensen, L

Malmö universitetsbibliotek

sara.kjellberg@mau.se

\title{
Forskarnas galleri - forskningskommunikation i det trovärdiga rummet
}

\section{Forskningskommunikation på bibliotek}

På Malmö universitetsbibliotek har vi länge diskuterat nya former för

forskningskommunikation i biblioteket. Med forskningskommunikation avser vi forskning som kommuniceras från akademin till det omgivande samhället. Redan för tio år sedan arbetade en grupp med dessa frågor utifrån samverkansperspektivet i projektet "Forskningskommunikation i det fysiska biblioteket" (Bergenäs et al., 2009). I projektets slutrapport finns förslag på olika nivåer av utställningsverksamhet i biblioteket, från enklare evenemang som kan förverkligas inom ramen för befintlig verksamhet till en permanent organisation kring ett forskarnas galleri där extra resurser är nödvändiga. (Bergenäs et al, s. 31ff). Sedan projektet avslutades har biblioteket skapat en organisatorisk hemvist för utställnings- och evenemangsverksamheten i Team lärandemiljö. Teamet, som består av nio personer från olika delar av biblioteksorganisationen, har utvecklat och ansvarar för evenemang som Forskning på tapeten, Bokstafetten och Studenternas galleri ${ }^{1}$.

Med dessa erfarenheter som utgångspunkt, formulerade vi en ansökan till Riksbankens jubileumsfond vid deras utlysning av kommunikationsprojekt. Vi tilldelades ett bidrag för att tillsammans med forskare göra universitetets forskning tillgänglig och synlig i form av utställningar på biblioteket. Vid tidpunkten för ansökan hade vi dedikerat en yta för utställningar, som vi benämnde boxen. Vi hade redan producerat ett par utställningar med fokus på ett dagsaktuellt ämne som vi lät forskare kommentera för att testa utställningsformen. Projektet Forskarnas galleri innebar en tydligare inriktning för utställningarna, att lyfta fram själva forskningen och att ge besökarna möjlighet till eftertanke och diskussion. Syftet med detta paper är att diskutera utställningsverksamhet på

\footnotetext{
${ }^{1}$ Läs mer om dessa arrangemang på Malmö universitetsbiblioteks webbplats https://www.mah.se/Bibliotek/Utstallningar-och-evenemang/
} 
högskole- och universitetsbibliotek utifrån de lärdomar vi fått under projekttiden. Vad innebär forskningskommunikation på bibliotek genom utställningar? Vad behövs för att skapa en utställning i biblioteket? Vilken betydelse har bibliotekarien för produktionen?

\section{Projektupplägg}

Projektets övergripande syfte var att testa nya former för forskningskommunikation genom utställningar i universitetets mest tillgängliga rum - biblioteket. En viktig aspekt av detta var att utforska en ny roll för bibliotekarier som utställningskuratorer. Nya arbetsuppgifter kopplade till utställningsverksamhet kräver nya arbetsformer och kompetenser. I artikeln "Curating Exhibitions in Academic Libraries: Practical Steps" beskrivs hur behovet av en ny yrkesroll som "librarian-curator" vuxit fram när de akademiska biblioteken funnit nya vägar för sin samverkan med akademin och allmänheten (Swanick, 2015). Vi ville testa konceptet bibliotekarie-kurator (vår översättning) i en svensk kontext och samtidigt utforska en ny form för forskningskommunikation baserad i biblioteket.

Ett av målen för projektet var att föreslå en organisation för ett strategiskt och långsiktigt arbete med utställningar som forskningskommunikation för ett lärosäte. Detta innebär dels att universitetets forskare ska känna till och utnyttja möjligheten att kommunicera forskning på detta sätt, dels att ha en arbetsmodell som underlättar och effektiviserar arbetet med utställningsproduktion.

Projektet hade två centrala utgångspunkter för arbetet: det fysiska rummets betydelse för kommunikation och interaktion och synen på biblioteksbesökaren som kunskapsproducent. I galleriet, som ligger centralt i biblioteket, ville vi förstärka bibliotekets roll som en plats för kunskapsväxling och möten (i både symbolisk och fysisk mening). Forskarnas galleri skulle bli en plats för nya möten; mellan forskare, studenter och allmänhet, mellan olika kompetenser inom universitetet, samt mellan forskningsresultat och biblioteksrummet. I utställningarna ville vi också lyfta fram boken som artefakt och utställningsobjekt. Boken kan illustrera, kommentera och fördjupa det forskningsfält som kommuniceras men har inte huvudrollen $\mathrm{i}$ våra utställningar. Inför varje utställning har vi bett forskarna att komma med inköpsförslag. På så sätt har arbetet med Forskarnas galleri inneburit en ny typ av kontextuellt förvärv.

Många besökare - studenter, forskare, skolelever eller allmänhet - går till biblioteket för att aktivt söka information. Vi har i projektet därför valt att betrakta biblioteksbesökaren som kunskapsproducent, snarare än passiv kunskapskonsument. Utställningarna i Forskarnas galleri, ska inte enbart besvara frågor eller presentera fakta, utan även väcka nya frågor och inspirera till fortsatt kunskapssökande.

Det refereras till de fyra senaste utställningarna i texten, därför kan det vara på sin plats att redan här berätta vilka de är²:

\footnotetext{
${ }^{2}$ https://www.mah.se/Bibliotek/Utstallningar-och-evenemang/Forskarnas-galleri/
} 
- Forskarnas galleri\#1 Kvinnor, klass, kultur - arbetet i litteraturen, från Maria Sandel till Daria Bogdanska

- Forskarnas galleri\#2 6 om sex - sexologi och sexualitetsstudier på Malmö högskola

- Forskarnas galleri\#3 Space \& Place - forskning om social hållbarhet i Malmö

- Forskarnas galleri\#4 Förnuft eller känsla? Fakta, forskning och föreställningar

\section{Ett reflekterande och iterativt arbete}

Projektet genomfördes med en följeforskare som stöd. Två bibliotekarier i Team lärandemiljö, anställdes som kuratorer på vardera 15 procent under ett års tid. Kompetensutveckling av kuratorer och teamet har skett genom studiebesök, skuggning, gemensam läsning och inte minst i det praktiska arbetet med att ta fram utställningar tillsammans. Till projektet knöts även en mentor eller creative advisor, Björn Magnusson Staaf, som är docent i museologi vid Lunds Universitet. Magnusson Staaf verkade både som inspiratör och som katalysator genom att han bidrog med sin forskning och kom med synpunkter på våra idéer under projekttiden.

Projektarbetet har inspirerats av aktionsforskning. En ständig växling mellan idé och test, utvärdering och ny idé har drivit och utvecklat arbetet vidare. Vi har genomgående haft ett reflekterande förhållningssätt vilket har gjort att vi utvecklat vår egen kunskap genom handling (Reason, 2008). Följeforskaren har löpande intervjuat både de deltagande bibliotekarierna och några av de forskare som deltagit i utställningarna. Intervjuerna har återkopplats in i projektarbetet och lett till nya tankar och idéer. Detsamma gäller erfarenheterna från att producera utställningarna som har använts för att kontrasteras mot tidigare forskning och andra inhämtade kunskaper.

Varje utställning hade sin egen process beroende på ämne och vem som deltagit i samarbetet. Vid nedmontering och avslut sammanställdes erfarenheterna och vi kom närmare en modell för hur vi ville lägga upp arbetet. All dokumentation av arbetet har skett $\mathrm{i}$ projektverktyget Trello för att skapa översikt och transparens, så att alla i projektet kunnat se vad de andra gjorde. Här skapades kolumner med rubriker som att göra, gjort, möten, idéer, gemensam läsning, reflektioner, synergieffekter och respons. För en del av arbetsgruppen fungerade Trello bra, som arbetsredskap eller projektyta. Andra tyckte att verktyget var ogenomträngligt. Att arbeta med utställningar är ett kreativt arbete och då upplevs Trello lätt som en bromskloss, eftersom man måste stanna upp i den kreativa processen för att dokumentera alla idéer. Det är dock viktigt att dela med sig så att alla känner sig inkluderade. Därför hade även ett arbetsrum för projektarbetet en viktig funktion. Här kunde arbetet synliggöras genom material och en whiteboardmålad vägg som fick skapa sammanhang för utställningsproduktionen. Under projekttiden använde vi olika utvärderings- och reflektionsformer, bland annat retrospektiv som ofta används i agil utveckling.

Under arbetet testades vår modell för utställningsproduktion i fem steg. Modellen innehåller beskrivning av utställningsproduktionens olika delar, checklistor för varje steg samt projektgruppens reflektion och litteraturtips, vilket vi återkommer till. 


\section{Forskningskommunikation och vetenskaplig kommunikation}

Forskning och vetenskap ser inte likadan ut inom olika discipliner. Olika ämnen har skilda traditioner för att kommunicera (Knorr Cetina, 1999). Gemensamt är att formell vetenskaplig kommunikation brukar innefatta skriftliga och granskade dokument som är lätta att lagra och mäta. Hit hör exempelvis vetenskapliga artiklar och monografier. Det finns också en informell vetenskaplig kommunikation som inte är granskad i strikt bemärkelse - den kan vara muntlig eller fångas upp i så kallad grå litteratur. Samtidigt har gränsen mellan informell och formell vetenskaplig kommunikation aldrig varit absolut och under senare år har detta blivit ännu mer påtagligt genom digital kommunikation som bloggar (Kjellberg, 2010). Forskningskommunikation till det omgivande samhället har utvecklats till att bli en tydligare del av den vetenskapliga praktiken. Idag ökar förväntningarna på forskare att delta i tredje uppgiften, det vill säga kommunicera med allmänhet och relevanta intressenter utanför akademin. Det kan ske på många sätt och ett skifte har skett från förmedling av forskning till att allmänheten har ett mer aktivt engagemang i den vetenskapliga processen (Horst, 2016).

Vetenskaplig kommunikation handlar också om att göra sig synlig som forskare. För forskarna är biblioteket en plats där de kan få stöd i forskningsprocessen. De använder kanske det fysiska rummet för möten eller egen kunskapsinhämtning. Vi menar att de med fördel även skulle kunna använda biblioteket och bibliotekariers kompetens för att kommunicera sin forskning utanför akademin.

\section{Rummets betydelse för utställningar}

Elmborg et al. utvidgar definitionen av biblioteket som rum genom att beskriva det som ett "third space" (Elmborg, 2015), ett tredje rum som uppmuntrar till dialog, möten, kreativitet och interaktion. I KB:s rapport "Den femte statsmakten" formuleras bibliotekens betydelse för det demokratiska samtalet, byggt på fakta och pluralism (Fichtelius, 2017, s.476). Här ses biblioteken som en oberoende och neutral kraft som förser användarna med kunskap för att kunna delta i detta samtal. På Malmö universitet talar vi om biblioteket som ett frirum, en informell lärandemiljö dit studenter och andra besökare kommer för att få hjälp att förstå den akademiska kontexten. Tankarna om frirummet som plats bygger vidare på det som projektet Högskolebibliotekets roll $i$ en inkluderande lärandemiljö utforskade om den fria lärandemiljö där bibliotekarien kan fungera som "epistemologisk tolk" (Giniewska, 2012). I biblioteket är det tillåtet att ställa frågor utan att bli bedömd. Frirum är ett begrepp som därför togs fram som en metafor för den plats som studenten frivilligt vänder sig till (Bergenäs et al, 2013). Biblioteket är dessutom ett offentligt rum och en mötesplats. Vi ser hela biblioteksmiljön som en trovärdig plats för tvärvetenskaplig samverkan mellan fakulteter, studenter, lärare, forskare och samhälle.

Biblioteket är ett rum för studier och kunskapsinhämtande, men också för upplevelser och överraskningar. Det är här den "tredje platsen" blir intressant som begrepp (Oldenburg, 1999) Arkitekten Aat Vos bygger vidare på Oldenburgs idéer om third space och beskriver en plats där det inte finns kommersiella intressen och där du har en möjlighet att lära och växa (Vos, 2017 s 13).

Många kommer till biblioteket när de befinner sig i en process, för att läsa, söka information, för att skriva eller för att samtala. Forskarnas galleri är både en sorts pausrum och ett kreativt inslag i studiemiljön. I galleriet får besökarna ta del av reflekterande utställningar 
om forskning. Som vi tidigare berörde har kommunikation av forskning och vetenskap öppnats upp för att i högre utsträckning bjuda in till dialog, debatt och deltagande (Horst, 2016).

För att få inspiration till arbetet med utställningsproduktion och skapa en djupare förståelse för hur vi kan utnyttja det rumsliga har studiebesök på flera institutioner som arbetar med forskningskommunikation spelat stor roll. Vi har bland annat besökt Danmarks Tekniske Universitet samt ett antal muséer i Sverige och Danmark, som Skissernas museum i Lund, Moesgaards museum i Århus och Malmö Museer. Här har vi sett hur rummet planeras och utnyttjas. Vi har studerat tekniska lösningar och översatt användandet av ljud, ljus, material och artefakter så att det passar i vårt galleri. Det var också givande att se hur dessa institutioner arbetar med organisation och planering av utställningar. Genom studiebesöken definierades och utvecklades vårt eget arbete.

\section{Från idé till praktik}

I Forskarnas galleri skapar vi ett narrativ och placerar in forskningen i ett sammanhang. Det är viktigt att hela teamet har en gemensam bild av den övergripande idén om utställningen "the big idea" (Serrell, s. 155ff). Idén kan skrivas ner i form av ett narrativ. Forskarna som deltagit i utställningsplaneringen får en visning av galleriet i början av processen. Vi berättar vilka ytor och möjligheter som finns och arbetar sedan vidare för att skapa ett gemensamt uttryck. Utställningsytan är flexibel, den kan både utökas och minskas. Det finns ett utanför och ett innanför boxen som man kan välja att utnyttja både bildligt och bokstavligt. Vi har byggt en skalenlig mindre modell av utställningsytan (boxen) där vi testar olika sätt att gestalta forskning. Galleriet blir ett rum där idéer föds och provas och forskarna gör, genom processen, rummet till sitt. På samma sätt öppnar utställningen sedan upp mot besökare att delta.

En reaktion från Björn Magnusson Staaf är att själva rummet är en överraskning i biblioteksmiljön. "Man kommer in och känner direkt att nu träder man in i någonting annat. Utan att läsa texterna eller fördjupa sig i materialet så förstår man vad utställningen handlar om." Det var ingenting vi hade formulerat för oss själva men vi tog det till oss och försökte sedan göra detta medvetet och tydligt i det fortsatta arbetet. Själva känslan och den rumsliga upplevelsen skulle vara central. Det var viktigt vilken ton som slogs an i utställningen. Gestaltningen skulle vara seriös men också lekfull. Vi ville bjuda in och uppmana till delaktighet och har därför interaktiva inslag i utställningarna och drar ifrån eller lägger till under utställningens gång beroende på besökarnas reaktioner

\section{Roller och samarbeten i utställningsproduktion}

I "Litteraere udstillinger i biblioteksrummet" tar Rune Eriksson (2017) upp skillnaden mellan exponering och kuratering av bokutställningar på folkbibliotek. En kuraterad litteraturutställning, menar Eriksson, har ingen ambition att vara neutral utan syftar istället till att poängtera ett angeläget ämne och sätta det i ett större sammanhang än vad en "vanlig" tematiserad bokutställning gör (Eriksson s. 176). När vetenskapliga bibliotek försöker hitta nya vägar för att kommunicera forskning genom utställningar krävs det någon som samordnar. Swanick et al (2015) beskriver behovet av en kurator. I projektet Forskarnas galleri har vi undersökt bibliotekariens roll som kurator. En kurators arbetsuppgifter kan variera. Traditionellt sett är kuratorn den person som väljer ut och tolkar det som ska ställas 
ut. Idag kan en kurator även vara producent, utställningsplanerare och pedagog. Att kuratera är att balansera mellan att tillfredsställa publikens behov av upplevelse och samtidigt ha respekt för konstnären - i vårt fall forskaren (George, 2015). På liknande sätt som Eriksson beskriver litteraturutställningar arbetar kurator-bibliotekarien med att illustrera forskning, men också med att få besökaren att reflektera över och ta ställning i frågor som belyses i utställningarna (Eriksson, 2017) På Malmö universitet ansvarar kuratorerna för att ta fram utställningsidé och innehåll. De samarbetar med forskarna och håller i produktionen av utställningarna. Det är också oftast kuratorn som har visningar av utställningen för besökare.

Vi arbetar med två kuratorer. Inledningsvis var detta ett sätt att underlätta kunskapsdelningen under projekttiden Det som blivit tydligt är dock att rollen blir mindre sårbar om det är två som delar på ansvaret. Samarbetet med forskarna blir också mer dynamiskt. Vi är vana vid att jobba i team och skapa verksamhet tillsammans, det gör arbetet mer mångfacetterat, mer kreativt och olika fokus och erfarenheter kan komma till uttryck. I rollen som bibliotekarie-kurator kan man lyfta varandra. Det är viktigt i alla steg, inte bara i forskarmötet, och vi tror att det skapar bättre kvalitet. Teamets nio medlemmar har varit aktiva i olika delar av utställningsverksamheten vid olika tillfällen. Vi har givna roller som projektledare, kuratorer, formgivare och ljussättare i arbetsgruppen, men vi har också varit öppna för att gå in och ut ur roller för att lära oss tillsammans (Robertson, 2013; Bäckström, 2016). Bäckström betonar det gemensamma lärandet:

"Var och en av deltagarna i den utställningsspecifika forskningsprocessen måste ikläda sig rollen som expert och lärare och rollen som novis och elev både vara kunnig och vilja lära ut och okunnig och villig att lära sig och därigenom vara med om att framställa allmänkunskap som är specifik för gruppen, en gemensam bildning." (Bäckström, 2016 s.21)

Arbetet har därmed inneburit en form av talangjakt i personalgruppen. Swanick uttrycker detta som att man ska "unleash hidden talents" (Swanick, 2015). Genom det har vi fått syn på befintliga kompetenser som textförfattande, formgivning, ljussättning, snickeri och filmning. Vi har uppmuntrat varandras kreativitet samtidigt som vi har respekterat varandras kompetenser. Vi har även tagit tillvara kompetenser som finns hos personer utanför teamet men i bibliotekspersonalen, till exempel ljussättning.

Målet har varit att i samarbete producera en forskningsinriktad utställning, i aktivt och nära samarbete med forskarna. Idén till utställningarna kom i första hand från kuratorerna men också från forskare eller forskningskommunikatörer. Vi arbetade med att göra forskarna delaktiga och utgå från deras idéer i planering och gestaltning av utställningarna. Därför var det viktigt att vara öppen och lyhörd i samtalen om hur forskningen skulle presenteras. Kontakt inför kommande utställning togs tre till sex månader före vernissage. Efter ett första informellt möte har vi haft mer strukturerade möten, workshops och kontakt via e-post med forskarna. Det är biblioteket som producerar utställningarna, men forskarna deltar i produktionsfasen på olika sätt beroende på hur mycket tid och intresse de har. Några har blivit intervjuade och skickat texter med e-post. Andra har varit mycket aktiva även i själva gestaltningen. 


\section{Delaktighet}

"Forskningsinformationen till allmänheten borde kunna förbättras. Mitt förslag är att universitetens reklam för den egna forskningen borde ransoneras en smula. I stället kan de få en fjärde uppgift: att folkbilda om hur forskning går till och vilka slutsatser man (inte) kan dra utifrån enskilda studier. Det är kanske svårare. Men nyttigare för allmänhet och samhälle." (Wold, 2017)

Forskaren och samhällsdebattören Agnes Wold har inspirerat oss att tänka mer kring att kommunicera hur forskning går till och sätta den i ett sammanhang. För att skapa intresse för forskning vill vi belysa förhållandet mellan vetenskap och samhälle genom frågebaserade utställningar. Frågorna får gärna vara kontroversiella, filosofiska eller etiska (Davidsson, 2009). Det finns mycket litteratur kring utställningsdesign (Serrell, 2015; George, 2015; Matassa, 2014; Bäckström, 2016). Alla har gett värdefulla insikter. Vi insåg snabbt att utställningarna i galleriet inte ska uppfattas som "presentationer" eller "a book on the wall" utan mer undersökande, öppna och interaktiva.

I Forskarnas galleri får man till exempel låna de utställda böckerna under pågående utställning. Vi vill uppmuntra till mer kunskapssökande och lärande och vi tror att lusten att lära hämmas om man inte får låna boken här och nu. Vi har löst det genom att göra litteraturlistor och fotokopior av bokomslag så att utställningen inte ser tom ut om en bok lånas. Böckerna i utställningen lånas flitigt vilket både kan tyda på att böckerna är mer synliga i utställningen än i hyllan och att det faktiskt är aktuella ämnen vi ställer ut.

En idé som vi har använt i två utställningar kom från en av forskarna under en workshop, ett tittskåp, där besökarna kan öppna luckor. I luckorna presenteras fakta, kuriosa eller tankeväckande frågor. Det är ett sätt att engagera och väcka nyfikenhet. Vi har också gett besökarna möjlighet att ställa frågor eller kommentera utställningarna. I utställningen om sexologi, Forskarnas galleri\#2, skedde detta genom en brevlåda i rummet. Frågorna som lämnades in projicerades sedan på en vägg i utställningen tillsammans med svar från forskarna. I utställningen om unga och social hållbarhet i Malmö, Forskarnas galleri\#3, kunde besökare rita hur de rör sig i staden på en stor karta på väggen, som nästan blev ett konstverk till slut av alla streck och vägar.

Forskarnas galleri\#4 baserades på forskning från alla fakulteter på universitetet och hade källkritik som tema. Här presenterades forskningsprojekten med provocerande frågor som: "Ska det vara tillåtet att knarka?", "Mer metall i käften?" eller "Är kolonialismens tid förbi?". Vår ambition var att få besökaren att tänka själv eller kanske söka svaret i forskningen. Den utställningen var en del av kampanjen \#Hurvetdudet som samordnas av Vetenskap \& Allmänhet ${ }^{3}$. I Forskarnas galleri\#3 deltog forskare som studerar en förskola i ett aktionsforskningsprojekt. Vi ställde ut forskning om förskolan och tog emot ett studiebesök av barnen, som producerade foton och teckningar till utställningen. På så sätt blev utställningen en del av ett av forskningsprojekten. Här möttes verkligen forskning och samhälle i galleriet och barnen gjorde utställningen till sin.

\footnotetext{
${ }^{3}$ https://hurvetdudet.nu/
} 
Vi har testat olika konstnärliga uttrycksformer och tekniska lösningar i utställningarna. Även om den fysiska framställningen har varit central så har vi sett att en digital representation $\mathrm{i}$ form av en webbsida ${ }^{4}$ är viktig för dokumentation, inspiration och inte minst spridning av aktuell utställning. Efter en forskares önskemål har vi även skapat en möjlighet att dokumentera utställningarna som "artistic work" i universitetets öppna arkiv, MUEP - något som nu görs löpande.

\section{Malmö universitetsbiblioteks 5-stegsmodell för utställningsproduktion}

Under projektet har vi bearbetat och ställt samma olika modeller för utställningsverksamhet och skapat en egen modell. Vi laborerade med olika steg under vägen och inför den sista utställningen hade vi konkretiserat en egen modell som vi kallar "Att bygga utställning - en modell i 5 steg från Malmö universitetsbibliotek" ${ }^{5}$. Vi kunde då testa den från start till produktion. De fem stegen är: idé, planering, produktion, utställningsperiod och avslut. Varje steg i modellen har tre delar; en beskrivning av vad respektive steg i processen innebär, en checklista över vad som ska göras och slutligen projektgruppens reflektioner kring de erfarenheter vi gjort under projektets gång. Under reflektioner finns också litteraturtips med böcker och artiklar som inspirerat oss. Grundläggande för modellen är att den bygger på samskapande och samarbete. Nedan är en sammanfattning av de olika stegen. Hela modellen finns tillgänglig i digital form där också varje steg inkluderar en checklista som gör det lättare att följa upp var man är i processen.

\section{Steg 1 - Idé}

Varje utställning börjar med att inventera idéer. Dessa kan komma från bibliotekets egen omvärldsbevakning av aktuell forskning inom universitetet och relevanta samhällsfrågor. Idéer kan också genereras genom en förfrågan från forskare/forskargrupp, förslag från kommunikatörer eller andra. Från grundidén formuleras ett syfte med utställningen. En hjälp kan vara att svara på frågorna:

- Vad vill vi kommunicera med utställningen?

- Varför vill vi kommunicera detta?

Under processen är det bra att kritiskt reflektera över ämne, frågeställning och genomförande.

\section{Steg 2 - Planering}

Det är viktigt att rollbesätta/bemanna ett utställningsteam redan tidigt i processen. En person kan ha flera roller och rollerna varierar från utställning till utställning. En central roll är den som kurator men man måste också definiera vem som ansvarar för till exempel design, teknik, medieinköp, programverksamhet och kommunikation. Det är även i planeringssteget som forskare engageras och möten och samtal sker enskilt eller i grupp. För att få idéer till utformningen anordnas workshops med utställningsteamet - med och utan forskare. Deltagarna funderar då över de tre utställningsdelarna - upplevelsedelen, informationsdelen och aktivitetsdelen.

\footnotetext{
${ }^{4}$ https://www.mah.se/Bibliotek/Utstallningar-och-evenemang/Forskarnas-galleri/

${ }^{5}$ Att producera utställning - en modell i 5 steg från Malmö universitetsbibliotek http://blogg.mah.se/forskarnas-galleri/
} 
Frågor att ta stöd $\mathrm{i}$ är:

- Hur gestaltar vi forskningen?

- Vad ska vi visa upp?

Det är också nu insamlandet av material påbörjas, till exempel befintlig litteratur, inköp av nya böcker, teknisk utrustning, möbler, artefakter. Det är viktigt att förankra idéer med hela utställningsteamet och med forskarna innan man går vidare till nästa steg.

\section{Steg 3 - Produktion}

Teammedlemmarna arbetar tillsammans med att producera utställningen enligt den rollfördelning som är bestämd. När teamet ska börja bygga är det praktiskt att göra en skiss, modell eller prototyp där olika idéer kan presenteras. Då blir det också enklare för forskarna att komma med idéer om hur deras ämne kan illustreras. I detta steg ingår även att producera kringmaterial som affischer och utställningsguide.

\section{Steg 4 - Utställningsperiod}

Utställningen invigs med vernissage där biblioteket och forskarna presenterar utställningen. Teamet sköter underhåll av och stödjer evenemang i anslutning till utställningen.

Evenemangen kan vara allmänna eller riktade till en speciell målgrupp och kan initieras av biblioteket eller av forskarna.

Kopplat till underhållet av utställningen, ingår också att svara på frågor och ta emot synpunkter från besökare. En digital representation av utställningen skapas på webben och kan byggas ut under utställningsperioden med bilder eller händelser som är kopplade till den.

\section{Steg 5 - Avslut}

Utställningen dokumenteras fortlöpande på webbsidan och på utsatt datum monteras den sedan ner. En möjlighet är att avsluta med ett evenemang i form av ett finissage där man också kan få återkoppling av både medverkande och besökare.

Varje utställning utvärderas utifrån följande frågor:

- Vad har utställningsteamet lärt sig (om utställningsproduktion)?

- Vad har målgruppen lärt sig om ämnet?

- Vad har forskarna lärt sig (till exempel om samverkan i nya former)?

Det är i detta steg som den bibliografiska posten i publikationsdatabasen skapas.

\section{Diskussion och slutsatser}

Under projektets gång har vi hittills producerat fyra utställningar i samarbete med 18 forskare från universitetets fem fakulteter. Nästa utställning är redan under planering tillsammans med ytterligare en grupp forskare. Utställningarna har tagits fram av projektets två kuratorer i samarbete med Team lärandemiljö. Eftersom arbetsformen för projektet inspirerats av aktionsforskning och en hög grad av reflektion med hjälp av följeforskaren fick deltagarna tid att läsa, diskutera och utvärdera. Detta gav processen ett djup och en medvetenhet som inte har funnits i tidigare utställningsverksamhet på biblioteket. Det har 
varit en utmaning att låta arbetet med utställningarna ta tid, att inte låsa sig vid idéer och att lita på varandra och processen. Genom att testa, formulera frågor, beskriva vad vi gjort och reflektera över det, har vi skaffat oss erfarenheter. På detta sätt har vi utvecklat verksamheten för varje utställning.

Forskningskommunikationen, det vill säga utställningarna och samarbetet, var huvudmålen med projektet. Ett parallellt mål har varit att ta fram en modell för utställningsproduktion som vi kan följa efter projektets slut, och dela med oss av till andra lärosäten.

Bibliotekarier har en funktion vid högskole- och universitetsbibliotek som något mittemellan stöd/service och akademi. De arbetar nära eller tillsammans med studenter i olika pedagogiska situationer. Detsamma gäller för andra samarbeten mellan forskare och bibliotekarier, exempelvis informationssökning eller publicering. Att bibliotekarier är integrerade i kärnverksamheterna utbildning och forskning har stärkt och fördjupat rollen som kurator.

En av de frågor vi ställde oss initialt är hur en roll som bibliotekarie-kurator kan utformas för att stödja och utveckla forskningskommunikation genom utställningar. Det har visat sig att en värdefull aspekt är bibliotekariens kompetenser kring referensintervjun eller referenssamtalet. Den typen av samtal är nödvändig för att få mer kunskap om forskning och skapa en gemensam bild av vad som är möjligt att göra. I samtalen med forskarna har det varit viktigt att ha en öppen inställning. Kuratorerna har förberett sig och läst på vilka projekt forskaren arbetar med. Ibland finns en idé om ett tema före mötet men ofta leder samtalet in på nya spår. Kuratorerna lyssnar och ställer frågor om det som forskaren berättar och försöker samtidigt tänka på hur forskningen kan gestaltas rent visuellt. Det har varit en fördel att dela kuratorskapet på två personer, eftersom rollen är ny har det inneburit att de två kunnat prova sig fram och reflektera tillsammans. Vid mötet med forskare har vi sett att det funnits ett förtroende för bibliotekets kompetens, som vi kunnat bygga vidare på i denna nya form för samarbete. I arbetet med Forskarnas galleri har vi talat om biblioteket som "den trovärdiga platsen". Vad som blev tydligt i möte med forskare är att även de uppfattar biblioteksrummet som en plats där de känner sig trygga att kommunicera sin forskning populärt, utan att den förvrängs eller förvanskas. En av de stora vinsterna med projektet har varit den fördjupade forskarkontakten som ibland lett till andra samarbeten; både mellan biblioteket och forskarna och mellan forskare från olika fakulteter. För bibliotekarierna som jobbat i projektet har det också inneburit att vi, förutom att vi lärt oss mer om utställningsproduktion, också fått en ökad förståelse för forskningsprocessen och forskningens villkor.

Arbetet med utställningar har alltså gett flera synergieffekter. En är att biblioteket har lärt mer om forskningen på universitetet vilket gör att vi kan ge bättre stöd till forskare. De deltagande forskarna har fått upp ögonen för biblioteket som ett rum för forskningskommunikation och en dörr till fler samarbeten har öppnats. En annan effekt är att forskare som inte hade träffats förut möttes och intresserade sig för varandras forskning. Speciellt intressanta blev mötena då vi arbetade i grupper med forskning från olika fakulteter. Där kunde den egna forskningen ses i relation till de andra forskargruppernas och de enskilda projekten sattes i ett sammanhang. Det är inte enbart samarbetet med forskarna som är värdefulla att etablera och bygga vidare på. Vi ser möjliga nya samarbeten med 
universitetets kommunikationsavdelning och hur studiebesök på museer och i andra verksamheter leder till fortsatt kontakt och samarbete.

De forskare som varit med och byggt utställningar har uttryckt att det är viktigt att kommunicera forskningen och att de känner sig trygga i samarbetet med biblioteket. Vi tror detta beror på att bibliotekarier är vana vid att arbeta med forskare i forskningsprocessen. Forskarna ser också möjligheter till att "återföra" sina resonemang och antaganden till det samhälle de undersöker. Besökarna får möjlighet att reagera, ifrågasätta och lägga till i diskussionen om forskningen som kommuniceras.

Det fanns en inneboende spänning i att ha modellen som ett mål eftersom vi också ville testa och vara fria i sättet som vi arbetade på. En modell med alltför många steg upplevde vi som styrande och bindande och därför kände vi ett behov av att förenkla modellen. Den är tänkt att vara ett stöd och en vägledning som man kan förhålla sig fritt till. Att ta fram en modell för utställningsproduktion, har synliggjort de olika stegen och gett oss en förståelse för att alla moment måste benämnas och tidsättas. Vissa moment är absolut avgörande för att nå ett lyckat resultat och det vi speciellt vill lyfta fram är kontakten med de medverkande forskarna. Kontakten har sett olika ut, men alltid inneburit ett möte i form av en eller flera intervjuer och ibland en workshop. Modellen gör arbetet tydligt och vi kan visa dem både hur vi vill arbeta och var vi befinner oss i processen.

Det är tydligt att forskningskommunikation genom utställningar i bibliotek får genomslag. Utställningar av det här slaget i samproduktion och samarbete är efterfrågade och ses som ett intressant tillägg för forskare och universitet i repertoaren kring övrig kommunikation av lärosätets forskning. Vi har undersökt vad som behövs för att skapa en utställning i biblioteket med fokus på bibliotekariens roll och också sammanställt en modell som andra nu får modifiera och använda. Rollen som bibliotekarie-kurator och biblioteksrummet som en arena för forskningskommunikation, är något vi vill fortsätta att utforska - gärna tillsammans med andra universitets- och högskolebibliotek. Vi efterlyser därför ett forum för kompetensdelning och erfarenhetsutbyte, där vi tillsammans kan hitta nya vägar att kommunicera forskning på bibliotek. 


\section{Litteraturförteckning}

Bergenäs, Elisabeth, Dorthé, Lotti, Olsson, Ann-Sofie, Schmitz, Ewa, Svensson, Anneli \& Tapia, Pablo (2009). Forskningskommunikation i det fysiska biblioteket. Biblioteket som en öppen mötesplats och ett ställe för samverkan? Malmö högskola, Bibliotek och IT Tillgänglig på Internet: http://hdl.handle.net/2043/8861

Bergenäs, Elisabeth, Hallberg, Ingrid, Helg Granbom, Anna, Rasmussen, Helen \& Zaar, Jessica (2013). Studenthandledning i frirummet: Bibliotek och Studieverkstad utforskar gränser. Tillgänglig på internet: $\underline{\text { http://hdl.handle.net/2043/15231 }}$

Bäckström, Mattias (2016). Att bygga innehåll med utställningar : utställningsproduktion som forskningprocess. Lund : Nordic Academic Press

Davidsson, Eva (2009). Enhancing Visitors' Interest in Science - A Possibility or A Paradox? Research in Science Education, Vol. 39 (2), s. 197-213

Elmborg, James, Jacobs, Heidi LM, McElroy, Kelly, \& Nelson, Robert (2015). Making a Third Space for Student Voices in Two Academic Libraries, Vol. 55(2), s.144-155.

Eriksson, Rune (2017). Litterære udstillinger i biblioteksrummet. Biblioteksdidaktik. Red. Cecilie Laskie. [København] : Hans Reitzel, s. 157-181

Fichtelius, Erik, Enarson, Eva, Hansson, Krister, Klein, Jesper \& Persson, Christina (red.) (2017). Den femte statsmakten: bibliotekens roll för demokrati, utbildning, tillgänglighet och digitalisering. [Stockholm]: Kungliga biblioteket, Nationell biblioteksstrategi

George, Adrian (2015). The curator's handbook : museums, commercial galleries, independent spacesLondon : Thames \& Hudson

Giniewska, Ewa, Lundgren, Ib, Rasmussen, Helen, Sedvall, Karin, Wogensen, Lotta, Zaar, Jessica \& Schmitz, Ewa (2012). Högskolebibliotekets roll i en inkluderande lärandemiljö: slutrapport.

Tillgänglig på internet: $\underline{\text { http://hdl.handle.net/2043/14310 }}$

Horst, Maja; Davies, Sarah Rachael; Irwin, Alan. Reframing Science Communication. The Handbook of Science and Technology Studies. Red. / Ulrike Felt; Rayvon Fouché; Clark A. Miller; Laurel Smith-Doerr. 4. ed. Cambridge : MIT Press, 2016 s. 881-907

Kjellberg, Sara (2010). Forskarbloggar: Vetenskaplig kommunikation och kunskapsproduktion i bloggosfären. Lunds universitet.

Knorr-Cetina, K. (1999). Epistemic cultures : how the sciences make knowledge. Cambridge, Mass.:Harvard University Press.

Matassa, Freda (2014). Organizing exhibitions: a handbook for museums, libraries and archives. London: Facet 
Oldenburg, Ray (1999). The great good place : cafés, coffee shops, bookstores, bars, hair salons, and other hangouts at the heart of a community. New York : Marlowe ; [Berkeley, Calif.]

Reason, Peter \& Bradbury, Hilary (red.) (2008). The SAGE handbook of action research: participative inquiry and practice. Los Angeles, [Calif.]: SAGE.

Robertson, Toni \& Simonsen, Jesper (2013) Participatory design: an introduction. Red. Simonsen, Jesper \& Robertson, Toni (red.) Routledge international handbook of participatory design. New York: Routledge. s. 21-38

Serrell, Beverly (2015). Exhibit labels: an interpretive approach. 2. ed. Maryland: Rowman et LittlefieldSwanick, Sean, Rankin, Sharon \& Reinhart, Melinda (2015). Curating Exhibitions in Academic Libraries: Practical Steps. Practical Academic Librarianship: The International Journal of the SLA, Vol. 5(2) s. 1-22.

Swanick, Sean, Rankin, Sharon \& Reinhart, Melinda (2015). Curating Exhibitions in Academic Libraries: Practical Steps. Practical Academic Librarianship: The International Journal of the $S L A$, vol. 5 nr. 2 s. $1-22$.

Wold, Agnes (2017). "Universitetets fjärde uppgift". Fokus. Hämtad på internet 30 augusti, 2018 från https://www.fokus.se/2017/06/universitetets-fjarde-uppgift/

Vos, Aat (2017). How to create a relevant public space. Rotterdam : nai010 uitgevers 